\title{
Quartile scores of scientific journals: Meaning, importance and usage
}

\author{
Bilimsel Dergilerin Q Değerleri: Anlamı, Önemi ve Kullanımı
}

\author{
Ahmet Asan ${ }^{1 *}$, Ahmet Aslan ${ }^{2}$ \\ 1 Trakya University Faculty of Science Department of Biology, Edirne, Turkey. \\ 2 Alanya Alaaddin Keykubat University, Faculty of Medicine, Department of Orthopedics and Traumatology, Alanya/Antalya, Turkey.
}

\section{ABSTRACT}

The $Q$ scores of scientific journals are an analytical tool that determines the ranking of journals based on their own scientific group and impact factor. It shows the rankings of the journal within its own group and it is a useful guide for researchers in the selection of the journal, however it should be used with caution in academic career advancement. Quartile scores may vary according to the scientific categories. The $Q$ scores of a journal briefly show the $25 \%$ quantile resulting from quartered the number of journals in the area where the journal is placed. The first quartile has the top $25 \%$ of the journals and gets the Q1 score and the last quartile gets Q4 score. And so, the second 25\% slice takes Q2 score and the third 25\% slice takes Q3 score.

\section{ÖZ}

Bilimsel dergilerin $Q$ değerleri, dergilerin kendi grubunda ve etki faktörüne bağı sıralamasını belirleyen analitik bir araçıı. Derginin kendi grubu içindeki sıralamasın gösterir, yararııır ve akademisyenlerin dergi seçiminde de yol göstericidir ancak akademik yükseltmelerde kullanılmasında dikkatli olunmalıdır. $Q$ değerleri bilimsel alanlara göre değişiklik gösterebilir. Bir derginin $Q$ değeri kısaca, derginin bulunduğu alandaki dergi sayısının dörde bölünmesiyle ortaya çıkan\% $25^{\prime}$ lik dilimleri gösterir IIlk\% 25 'lik dilim Q1 değerini alırken, son\% 25 'lik dilim Q4 değerini alır. Dolayısıyle ikinci\% 25'lik dilim Q2, üçüncü\% $25^{\prime}$ lik dilim ise Q3 değerini alır.

Received: 01.12.2019 Accepted: 28.12.2020 Published (Online):02.03.2020

*Corresponding Author: Ahmet Asan, Prof. Dr. PhD. Trakya University Faculty of Science Department of Biology, Edirne, Turkey, Phone: +90 284 2352824/1219 mail: ahmetasan84@gmail.com

ORCID: 0000-0002-4132-3848

To cited: Asan A, Aslan A. Quartile scores of scientific journals: meaning, importance and usage. Acta Med. Alanya 2020;4(1):102-108. doi:10.30565/medalanya.653661 


\section{INTRODUCTION}

$\mathbf{V}^{2}$ arious analytical sources are used to measure the output of scientific journals, authors and institutions, etc. One of the most well-known of these is the impact factor (IF) of journals. The impact factor term is related to the citations of full text and review articles published in a journal, per full text or review articles, in the following years. The calculation of the impact factor is based on the performance of the scientific journal in the last three years. Calculation of impact factor can be explained with an example: For instance, a journal publishes 80 articles (x) in two years (2017 and 2018 ) and these 80 articles receive 160 citations (y) in 2019. Therefore, the impact factor score of this journal for 2019 will be $(y / x)=160 / 80=2$. Namely, the last three years are always taken into consideration for the calculation of impact factor, but 5-year impact factors can also be calculated and published every year in the Web of Science database. The high number of citations received per article increases the impact factor scores. However, articles that do not receive potentially citations may increase the number in the denominator and may decrease the impact factor score [1-3].

Why did we begin with the impact factor score when trying to explain the $Q$ scores of scientific journals? Because the $Q$ scores are more directly related to the impact factor scores.

\section{Calculation and Quartile Scores of Scientific Journals}

The $Q$ score is derived from the English word "quartile" and signifies a quarter. To calculate the $Q$ score of a journal, it is necessary to know the number of journals in the category placed in the said journal. As in the Web of Science [4] database, journals covered by SCI-Expanded are grouped by scientific category; without this grouping, the $Q$ score of journals cannot be calculated. For example, there are 40 journals in the category $x$ and 96 journals in the category $y$. The impact factor scores of the these journals for the last year are determined. We can explain the $Q$ score with an example: If there are 120 journals in category z covered by SCI-Expanded database: 120 journals ranked from 1 to 120 according to the impact factor scores. The number 120 is divided by four, and four quarters are obtained for taking Q scores (Table 1).

\begin{tabular}{|l|l|}
\hline Journal Score & Definition \\
\hline Q1 & $\begin{array}{l}\text { Top 25\% of the highest impact factor score of journals } \\
\text { in a scientific category. }\end{array}$ \\
\hline Q2 & $\begin{array}{l}\text { Second, 25\% of the highest impact factor score of } \\
\text { journals in a scientific category. }\end{array}$ \\
\hline Q3 & $\begin{array}{l}\text { Third, 25\% of the highest impact factor score of jour- } \\
\text { nals in a scientific category. }\end{array}$ \\
\hline Q4 & $\begin{array}{l}\text { The last 25\% of the highest impact factor score of } \\
\text { journals in a scientific category. }\end{array}$ \\
\hline
\end{tabular}

Thirty journals in the first category with the highest impact factor score are Q1, the second 30 journals are Q2, the third 30 journals are Q3, and the last 30 journals are Q4. More information on this can be found on the website [5] and even further information can be found on this subject in Tonta's article [6]. Q scores of journals are given in $25 \%$ slices, but the number of publications in journals is not compatible with this. For example, Liu et al. stated that $33.33 \%(1 / 3)$ of the publications were published in Q1 journals and $16.5 \%$ in Q4 journals, according to the JCR 2015 [7]. However, sometimes a journal can have more than one $Q$ score because of a journal can sometimes participate in more than one scientific category [7].

\section{Meaning and Usage of Quartile Scores of Scientific Journals}

The $Q$ scores of the journals give us information about the citation performance of given journal and its place in the community of journals in the given scientific category. In addition, researchers may use the $Q$ scores to inform themselves of the status of the journal when selecting a journal for submission of a manuscript. However, when an academician is appointed to the academic personnel, the situation changes if some institutions ask which $Q$ score journals this academician publishes his papers in. If a journal has more than one $Q$ score, which $Q$ score should be considered by the employer? Taking into account the highest $Q$ score can be rational and fair, however if the person publishes a paper(s) in the $x$ scientific category and the $Q$ score of the y scientific category is taken into consideration, it will result in a score being attributed to this person's publication, though the article in question 
is not, in fact, in the y scientific category. Therefore great care should be taken where an academician may receive points for academic progress from a scientific category where they are actually not published in.

Q scores of journals are generally available from databases such as SCImago and Web of Science $[4,8]$. $Q$ scores of the journals for the last year can be accessed via the latter and SCImago also provides $Q$ values for the previous years, however the $Q$ scores of a journal may be different depending on the database consulted because the number of journals covered is different, and as a result the number of citations of journals will also be different. Here are examples to illustrate this fact: according to information found on the website SCOPUS, the Academic Radiology Journal was Q1 for the year 2016, while for the same year in the Web of Science database it was Q2. In the same way, the Journal of Cancer Education covered in SCOPUS for 2018 was in the category of oncology 215/320 (Q3), while it was ranked 203/230 in the category of oncology for 2018 (Q4) in the Web of Science. These indicate that the $Q$ scores of journals may differ from one database to another [9].

If we only take the Web of Science database into account, the $Q$ scores of journals can be found for the last year only (for example, if we are in the 2019 year, the latest available data is from 2018). In this case, which $Q$ score will the academician consider to be nominated? Inversely, if taking the Web of Science into consideration is mandatory and an academician cannot access the $Q$ value of the journal for a paper, for example, published in 2015 , he/she must take into account the last $Q$ score available, say 2018. Invariably, Q scores of journals may differ from year to year and a journal with Q4 score in 2015 may be attributed Q2 or Q3 in 2018, and in such a case the scoring may be incorrect. Furthermore, Q scores also can vary in themselves. For example, if there are 200 journals in any scientific category (for example, there are 203 journals in the Web of Science of surgery category), so $200 / 4=50$, would be 50 journals per $25 \%$ slice, meaning there are 50 journals in Q1. This number also means that both the first and the 50th journals are in the Q1 category. However, impact factor scores of the first journal and 50th journal are different and thus a researcher who publishes in the journal ranked 50th and a researcher who publishes in the journal ranked 1 st will receive the same score. Another issue is that the journal ranked 51st will receive a Q2 score, however the difference between 50th and 51 st journals is usually very narrow. This can be explained through an example: according to the Web of Science 2018 data, there are 223 journals in the category of oncology. Among these journals, the journal with the impact factor score of 223.679 in 2018 and in the Q1 category is Ca-A Cancer Research for Clinicians. The impact factor score of Cancer Science, which is 57 th in the oncology category and is also Q1, is 4.751. In this case, the paper of an academician published in $\mathrm{Ca}-\mathrm{A}$ Cancer Research for Clinicians and the paper of an academician published in Cancer Science will receive the same score, because they are both in the Q1 category. However, the impact factor score of the first journal is an extraordinary score of 223.679, whereas the impact factor score of the 57 th journal is 4.751 , which are considerably different. There is in fact a 47.08 -fold difference in the impact factor score between the two journals. Here, not only the 57th rank but as an example, the Annals of Oncology, ranked 9th - with a 14.196 impact factor score - is far behind the impact factor score of the first-ranked journal. The American Journal of Cancer Research ranked 58th in the oncology category, is in the Q2 category because of its impact factor score of 4.737 for the year 2018. However, the difference between the impact factor score of the 57th journal and the impact factor score of the 58th journal is only 0.014 though persons who published papers in these two journals will receive different scores or points. As the number of journals in a scientific category increases, so also increases the difference in the impact factor score. As an example of this effect, the Web of Science biochemistry-molecular biology scientific category has 299 journals for the year 2018: accordingly, in terms of impact factor score, the journal in the 1st and 75th rank will receive Q1 score and be calculated with the same score. However, impact factor scores of the first and 75th journals are not equal [10].

As the number of journals in one scientific category decreases, the difference decreases as well. In short, as the scientific category is 
specific, the number of journals in the scientific category decreases and the number of journals in the scientific category increases, as the scientific category becomes general. For example, according to 2018 data in the Web of Science database, there are 27 journals in allergy, 29 in mycology, 76 in orthopedics, 128 in immunology, and 160 in general medicine. That is to say, the number of journals are increasing progressively towards the general scientific category [10]. Campanario indicated the way self-citations of 51 selected journals from the JCR-SCl field affect the journal's impact factor and $Q$ scores [11]. Tayyab and Boyce reported that the impact factor scores of 39 journals selected from different scientific disciplines in the Q1 category ranged from 0.611-1.979 (below 2), whereas the journals in the biochemistry-molecular biology category were at least 4.405 and above [12]. In other words, impact factor and $Q$ scores of journals vary according to the scientific category. According to the information provided by Tayyab and Boyce's article, the journal in each Q1 category may not have a high impact factor score [12]. Miranda and Garcia-Carpintero have already indicated that the $Q$ scores of journals differ according to the scientific categories [13].

Status of Turkey's Scientific Journals:

$Q$ scores of journals are used as academic incentives in Turkey [14]. The $Q$ categories of Turkey's Journals show that we need to make more efforts in this regard as unfortunately, there are no journals in the Q1 category among our journals covered by SCI-Expanded and SSCI [15]. We presented $Q$ scores of Turkish journals covered by SCl-Expanded, SSCl and SCIMagoSCOPUS in Table 2. There is no any journal in category Q1 covered by SCI-Expanded and SSCI databases but there are 5 journals in category Q1 in SCIMago-SCOPUS because of number of journals is different than in the previously mentioned databases (Table 2). Two journals (Atmospheric Pollution Research, Turkish Journal of Agriculture and Forestry) are in category Q2 in SCl-Expanded and SSCl databases, others are category Q3 and Q4. Data presented in Table 2 are the latest, though new data (2019) is expected to be published in June or July, 2020.
The $Q$ scores of scientific journals provide valuable information in terms of citation and ranking in their scientific categories, and they are beneficial. They can also be useful for the selection of journals for academicians to submit manuscripts to, and can guide them adequately in this regard. However, the use of the $Q$ scores of the journals for the purpose of academic staff appointments have the potential of being misinterpreted, and therefore caution is warranted and recommended.

Conflict of interests: The authors declare that there is no conflict of interests.

Funding sources: There is no source of funding or financial interest in this study. 
Table 2. Q Scores of Journals Originated from Turkey.

\begin{tabular}{|c|c|c|}
\hline $\begin{array}{l}\text { Title of Journal (alphabetical order) (Total: } \\
13,608 \text { journals; } 63 \text { journals are originated from } \\
\text { Turkey) }\end{array}$ & Q Score of Journal (Web of Science Database) (2018) & $\begin{array}{l}\text { Q Score of Journal ** (SCIMago by SCOPUS } \\
\text { Database) (2018) }\end{array}$ \\
\hline \multicolumn{3}{|l|}{ Covered by SCI-Expanded } \\
\hline Acta Orthopaedica Et Traumatologica Turcica & Q4 (64 of 76) & Q3 \\
\hline $\begin{array}{l}\text { Anadolu Psikiyatri Dergisi - Anatolian Journal } \\
\text { of Psychiatry }\end{array}$ & Q4 (144 of 146) & Q4 \\
\hline $\begin{array}{l}\text { Anatolian Journal of Cardiology (Former title: } \\
\text { Anadolu Kardiyoloji Dergisi/The Anatolian } \\
\text { Journal of Cardiology }\end{array}$ & Q4 (122 of 136) & Q3 \\
\hline Ankara Universitesi Veteriner Fakultesi Dergisi & Q4 (122 of 141) & $\begin{array}{l}\text { Q3 (Veterinary, Misc.). Q4 (Animal Sci-Zool- } \\
\text { ogy) }\end{array}$ \\
\hline $\begin{array}{l}\text { Archives of Rheumatology (Former title: } 2 \text { : } \\
\text { Turkish Journal of Rheumatology (1: Romatiz- } \\
\text { ma-Rheumatism) }\end{array}$ & Q4 (30 of 31) & Q4 \\
\hline Atmospheric Pollution Research & $\mathrm{Q} 2(90$ of 251$)$ & $\begin{array}{l}\text { Q1 (Waste Management and Disposal). Q2 } \\
\text { (Atmosphric Sci, Pollution) }\end{array}$ \\
\hline $\begin{array}{l}\text { Balkan Medical Journal (Former title: Trakya } \\
\text { Universitesi Tip Fakultesi Dergisi) }\end{array}$ & Q3 (94 of 160) & Q3 \\
\hline Diagnostic and Interventional Radiology & Q4 (97 of 129) & Q2 \\
\hline $\begin{array}{l}\text { Eklem Hastaliklari ve Cerrahisi / Joint Diseases } \\
\text { and Related Surgery }\end{array}$ & Q4 (Orthopedics: 58 of 76). Q4 (Surgery:163 of 203) & $\begin{array}{l}\text { Q2 (Rehabilitation). Q3 (Surgery; Orthopedics; } \\
\text { and Sports Medicine). }\end{array}$ \\
\hline Experimental and Clinical Transplantation & Q4 (25 of 25$)$ & Q3 \\
\hline Hacettepe Journal of Mathematics and Statistics & $\begin{array}{l}\text { Q3 (Mathematics: } 207 \text { of 314).Q4 (Statistics \& Proba- } \\
\text { bility:105 of 123) }\end{array}$ & Q3 \\
\hline $\begin{array}{l}\text { Isi Bilimi ve Teknigi Dergisi - Journal of Ther- } \\
\text { mal Science and Technology }\end{array}$ & $\begin{array}{l}\text { Q4 (Engineering, Mechanical: } 126 \text { of 129). Q4 (Ther- } \\
\text { modynamic: } 58 \text { of } 60 \text { ) }\end{array}$ & $\begin{array}{l}\text { Q2 (Engineering). Q3 (Materials Science). Q4 } \\
\text { (Atomic and Molecular Physics, and Optics) }\end{array}$ \\
\hline $\begin{array}{l}\text { Journal of Agricultural Sciences-Tarım Bilimleri } \\
\text { Dergisi }\end{array}$ & Q4 (54 of 57) & Q4 \\
\hline $\begin{array}{l}\text { Journal of Clinical Research In Pediatric } \\
\text { Endocrinology }\end{array}$ & $\begin{array}{l}\text { Q3 (Pediatrics: } 85 \text { of 125). Q4 (Endocrinology \& Me- } \\
\text { tabolism:131 of 145) }\end{array}$ & $\begin{array}{l}\text { Q2 (Pediatrics, Perinatology and Child Health). } \\
\text { Q3 (Endocrinology; Diabetes and Metabolism) }\end{array}$ \\
\hline $\begin{array}{l}\text { Journal of International Advanced Otology (for- } \\
\text { mer title: Mediterranean Journal of Otology) }\end{array}$ & $\mathrm{Q} 4(40$ of 42$)$ & Q2 (Medicine). Q3 (Otorhinolaryngology) \\
\hline Journal of Neurological Sciences-Turkish & Q4 (267 of 267) & Q4 \\
\hline Journal of Sports Science and Medicine & Q3 (50 of 83) & $\begin{array}{l}\text { Q1 (Orthopedics and Sports Medicine; Physical } \\
\text { Therapy, Sports Therapy and Rehab). } \\
\text { Q2 (Sports Science) }\end{array}$ \\
\hline Journal of the Entomological Research Society & Q4 (98 of 98$)$ & Q4 \\
\hline $\begin{array}{l}\text { Journal of the Faculty of Engineering and Archi- } \\
\text { tecture of Gazi University }\end{array}$ & Q4 (76 of 88$)$ & Q1 (Architecture). Q2 (Engineering, Misc.) \\
\hline Kafkas Universitesi Veteriner Fakultesi Dergisi & Q4 (111 of 141) & Q3 \\
\hline Mikrobiyoloji Bulteni & Q4 (130 of 133) & $\begin{array}{l}\text { Q3 (Microbiology, Medicine, Inf. Disease). Q4 } \\
\text { (Immunology and Microbiology) }\end{array}$ \\
\hline Neurological Sciences and Neurophysiology & $\begin{array}{l}\text { *(Because of covered by SCI-Expanded since Dec.25, } \\
2018)\end{array}$ & $*$ \\
\hline $\begin{array}{l}\text { Noropsikiyatri Arsivi-Archives of Neuropsychi- } \\
\text { atry }\end{array}$ & Q4 (189 of 199) & $\begin{array}{l}\text { Q3 (Psychiatry and Mental Health).Q4 (Neu- } \\
\text { roscience) }\end{array}$ \\
\hline $\begin{array}{l}\text { Psychiatry and Clinical Psychopharmacology } \\
\text { (Klinik Psiko-farmakoloji Bulteni-Bulletin of } \\
\text { Clinical Psychopharmacology) }\end{array}$ & $\begin{array}{l}\text { Q4 (Pharmacology \& Pharmacy: } 259 \text { of 267). Q4 (Psy- } \\
\text { chiatry } 141 \text { of 146). }\end{array}$ & $*$ \\
\hline Records of Natural Products & $\begin{array}{l}\text { Q3 (Chemistry,Applied:48 of 71). Q3 (Chemistry, Me- } \\
\text { dicinal:53 of 61): Q4 (Plant Sciences:138 of 228): }\end{array}$ & $\begin{array}{l}\text { Q2 (Plant Science). Q3 (Pharmacology; Organic } \\
\text { Chemistry; Drug Discovery) }\end{array}$ \\
\hline
\end{tabular}


Table 2. Continued

\begin{tabular}{|c|c|c|}
\hline Teknik Dergi & Q4 (131 of 132) & Q4 \\
\hline Tekstil ve Konfeksiyon & $\mathrm{Q} 4$ (23 of 24$)$ & Q3 \\
\hline $\begin{array}{l}\text { Turk Gogus Kalp Damar Cerrahisi Dergi- } \\
\text { si-Turkish Journal of Thoracic and Cardiovascu- } \\
\text { lar Surgery }\end{array}$ & Q4 (202 of 203) & * \\
\hline Turkish Journal of Agriculture and Forestry & $\mathrm{Q} 2(32$ of 89$)$ & Q1 (Forestry). Q2 (Agriculture; Ecology) \\
\hline $\begin{array}{l}\text { Turkish Journal of Biochemistry-Turk Biyok- } \\
\text { imya Dergisi }\end{array}$ & Q4 (296 of 299) & Q4 \\
\hline Turkish Journal of Biology & Q4 (76 of 87) & $\begin{array}{l}\text { Q3 (Agriculture\&Biological Sci) Q4 (Cell Biolo- } \\
\text { gy; Genetics; Microbiology; Mol.Biology) }\end{array}$ \\
\hline Turkish Journal of Botany & Q3 (152 of 228) & Q2 \\
\hline Turkish Journal of Chemistry & $\begin{array}{l}\text { Q3 (Engineering, Chemical:103 of 138). Q4 (Chemis- } \\
\text { try,137 of 172) }\end{array}$ & Q3 \\
\hline Turkish Journal of Earth Sciences & Q3 (145 of 196) & Q2 \\
\hline $\begin{array}{l}\text { Turkish Journal of Electrical Engineering and } \\
\text { Computer Sciences }\end{array}$ & $\begin{array}{l}\text { Q4 (Computer Science, Artificial Intelligence: } 125 \text { of } \\
\text { 134). Q4 (Computer Science, Artificial Intelligence: } 125 \\
\text { of 134) }\end{array}$ & Q3 \\
\hline Turkish Journal of Field Crops & Q4 (69 of 89) & Q2 \\
\hline \multirow{2}{*}{$\begin{array}{l}\text { Turkish Journal of Fisheries and Aquatic } \\
\text { Sciences }\end{array}$} & Q4 Fisheries:43 of 52). & Q3 \\
\hline & Q4 (Marine Biology: 92 of 108) & \\
\hline Turkish Journal of Gastroenterology & Q4 (81 of 84$)$ & Q3 \\
\hline $\begin{array}{l}\text { Turkish Journal of Geriatrics-Turk Geriatri } \\
\text { Dergisi (+SSCI) }\end{array}$ & $\begin{array}{l}\text { Q4 (Geriatrics \& Gerontology:53 of 53).Q4 (Gerontol- } \\
\text { ogy:35 of } 36) .\end{array}$ & Q4 \\
\hline Turkish Journal of Hematology & $\mathrm{Q} 4(70$ of 73$)$ & $*$ \\
\hline Turkish Journal of Mathematics & Q3 (211 of 314) & Q3 \\
\hline Turkish Journal of Medical Sciences & Q4 (138 of 160) & Q3 \\
\hline Turkish Journal of Pediatrics & Q4 (123 of 125) & Q3 \\
\hline $\begin{array}{l}\text { Turkish Journal of Physical Medicine and } \\
\text { Rehabilitation }\end{array}$ & $\mathrm{Q} 4(65$ of 65$)$ & Q4 \\
\hline Turkish Journal of Veterinary \& Animal Sciences & Q3 (104 of 141) & Q3 \\
\hline Turkish Journal of Zoology & Q4 (143 of 170) & Q3 \\
\hline Turkish Neurosurgery & $\begin{array}{l}\text { Q4 (Clinical Neurology:187 of 199). Q4 (Surgery: } 175 \\
\text { of 203) }\end{array}$ & Q3 \\
\hline $\begin{array}{l}\text { Turkiye Entomoloji Dergisi-Turkish Journal of } \\
\text { Entomology }\end{array}$ & $\mathrm{Q} 3(70$ of 98$)$ & Q3 \\
\hline $\begin{array}{l}\text { UHOD-Uluslararasi Hematoloji-Onkoloji } \\
\text { Dergisi }\end{array}$ & $\mathrm{Q} 4(204$ of 230$)$ & Q4 \\
\hline $\begin{array}{l}\text { Ulusal Travma ve Acil Cerrahi Dergisi- Turkish } \\
\text { Journal of Trauma \& Emergency Surgery }\end{array}$ & Q4 (24 of 29). & Q3 \\
\hline \multicolumn{3}{|l|}{ Covered by SSCI } \\
\hline Amme Idaresi Dergisi & $\mathrm{Q} 4(46$ of 47$)$ & Q4 \\
\hline Bilig & Q4 (72 of 74) & Q3 \\
\hline Egitim ve Bilim-Education and Science & Q4 (216 of 243$)$ & Q3 \\
\hline New Perspectives on Turkey & Q3 (65 of 104) & $\begin{array}{l}\text { Q1 (Cultural Studies; History). Q3 (Sociology } \\
\text { and Political Sci; Economics- Econometri) }\end{array}$ \\
\hline Turk Psikiyatri Dergisi & Q4 (136 of 142) & $*$ \\
\hline Turk Psikoloji Dergisi & Q4 (136 of 137) & Q4 \\
\hline $\begin{array}{l}\text { Turkish Journal of Geriatrics-Turk Geriatri } \\
\text { Dergisi }\end{array}$ & Q4 (Geriatrics 53 of 53). Q4 (Gerontology: 35 of 36). & Q4 \\
\hline Uluslararasi Iliskiler-International Relations & $\mathrm{Q} 4$ (91 of 91$)$ & Q4 \\
\hline
\end{tabular}


Asan A and Aslan A. Quartile Scores of Scientific Journals

Table 2. Continued

Covered by AH\&CI (Clarivate Analytics do not publish impact factors of AH\&CI journals)

\begin{tabular}{|l|l|l|}
\hline Adalya & $*$ & $\begin{array}{l}\text { Q2 (Archeology, Conservation, History). Q3: } \\
\text { (Archeology) (2017) }\end{array}$ \\
\hline Belleten & $*$ & Q3 (History). Q4 (Cultural Studies) \\
\hline METU Journal of The Faculty of Architecture & $*$ & Q2 (Architecture) \\
\hline Milli Folklor & $*$ & Q2 (Cultural Studies). Q3 (Art and Humanities) \\
\hline Olba & $*$ & Q4 (Archeology) \\
\hline $\begin{array}{l}\text { Osmanli Arastirmalari-The Journal of Ottoman } \\
\text { Studies }\end{array}$ & $*$ & Q3 (Cultural Studies, History) \\
\hline
\end{tabular}

*No data

**https://www.scimagojr.com/ (Total: 31,971 journals; 219 journals are originated from Turkey)

\section{REFERENCES}

1. Garfield E. Use of Journal Citation Reports and Journal Performance Indicators in measuring short and long term journal impact. Croat Med J. 2000;41(4):368-74. PMID: 11063757

2. https://clarivate.com/webofsciencegroup/essays/impact-fact Available 25.11.2019

3. Asan A. [International Journal Indexes, Importance and Status of Turkey Journals: Part 1. Scientific Journal Indexes.] Turkish. Acta Med. Alanya 2017:1(1):33-42. doi:10.30565/medalanya.303599

4. https://mjl.clarivate.com/home Available 30.11.2019

5. https://researchassessment.fbk.eu/quartile_score Available 01.12.2019

6. Tonta, Y. [Journals Published in Turkey and Indexed in the Web of Science: An Evaluation]. Türk Kütüphaneciliği. 2017;31(4):449-82. doi: 10.24146/tkd.2017.21

7. Liu W, Hu G, Gu M. The probability of publishing in first-quartile journals. Scientometrics. 2016;106 (3):1273-1276. doi:10.1007/s11192-015-1821-1

8. https://www.scimagoj.com/ Available 01.12.2019

9. Delgado-López-Cózar E, Cabezas-Clavijo, A. (2013). Ranking journals: Could Google scholar metrics be an alternative to Journal Citation Reports and SCImago journal rank? Learned Publishing, 2013; 26(2):101-114. doi: 10.1087/20130206

10. Numerical data obtained from Web of Science Database, As of January 18,2020

11. Campanario J. Journals that rise from the fourth quartile to the first quartile in six years or less: Mechanisms of change and the role of journal self-citations. Publications. 2018;6(4):47. doi:10.3390/publications6040047

12. Tayyab S, Boyce AN. Impact factor versus Q1 class of journals in world university rankings. Current Science. 2013;104 (4): 417-419.

13. Miranda R, Garcia-Carpintero E. Comparison of the share of documents and citations from different quartile journals in 25 research areas. Scientometrics. 2019;121(1):479-501. doi: 10.1007/s11192-019-03210-z

14. https://www.resmigazete.gov.tr/eskiler/2020/01/20200117-9.pdf Available:18.01.2020

15. Asan A. [International Journal Indexes, Importance and Status of Turkey Journals: Part 2: Situation of Turkey.] Turkish. Acta Med. Alanya 2017;1(1):43-54. doi:10.30565/medalanya.303602 